Bull. Chem. Soc. Ethiop. 2018, 32(3), 481-490.

ISSN 1011-3924

(c) 2018 Chemical Society of Ethiopia and The Authors

Printed in Ethiopia

DOI: https://dx.doi.org/10.4314/bcse.v32i3.7

\title{
SYNTHESIS, STRUCTURAL AND PHOTO-PHYSICAL STUDIES OF TRANSITION METAL COMPLEXES WITH MANNICH BASES DERIVED FROM 2-MERCAPTOBENZIMIDAZOLE
}

\author{
Amna Farooq ${ }^{1}$, Muhammad Imran ${ }^{1 *}$, Zafar Iqbal $^{2}$, Tanveer Hussain Bokhari ${ }^{3}$, \\ Shoomaila Latif ${ }^{4}$, Ayesha Farooq ${ }^{1}$, Muhammad Liaqat $^{1}$ and Liviu Mitu ${ }^{5 *}$ \\ ${ }^{1}$ Institute of Chemistry, University of the Punjab, Lahore, Pakistan \\ ${ }^{2}$ Department of Chemistry, Syed Babar Ali School of Science and Engineering, \\ Lahore University of Management Sciences (LUMS), DHA, \\ Lahore Cantt-54792, Lahore, Pakistan \\ ${ }^{3}$ Department of Chemistry, Goveronment College University, Faisalabad, Pakistan \\ ${ }^{4}$ Department of Chemistry, University of Lahore, Lahore, Pakistan \\ ${ }^{5}$ Department of Nature Sciences, University of Pitesti, Pitesti, 110040, Romania
}

(Received December 03, 2017; Revised September 25, 2018; Accepted October 1, 2018)

\begin{abstract}
Two Mannich base ligands, [1-(di- $n$-butylamine- $N$-methyl)mercapto- $1 H$-benzimidazole] $\left(\mathbf{L}^{1}\right)$ and [1-(diphenylamine- $N$-methyl)mercapto-1H-benzimidazole] $\left(\mathbf{L}^{2}\right)$ have been synthesized and further reacted with $\mathrm{Co}(\mathrm{II}), \mathrm{Ni}(\mathrm{II}), \mathrm{Cu}(\mathrm{II})$ and $\mathrm{Zn}$ (II) ions to afford their respective complexes. The progress of the reaction was monitored by thin layer chromatography. The structural elucidation of Mannich base ligands and their metal complexes was done by Fourier Transform Infrared (FTIR), UV-Visible, Nuclear Magnetic Resonance spectroscopy ( ${ }^{1} \mathrm{H}$ NMR \& ${ }^{13} \mathrm{C}$ NMR) and Atomic absorption spectroscopy (AAS) / Inductively coupled plasma emission spectroscopy (ICPES). FTIR and NMR studies supported the monoanionic bidentate coordination mode of $\mathrm{L}^{1}$ and $\mathrm{L}^{2}$ while tetrahedral geometries of metal complexes were proposed on the basis of AAS/ICP, magnetic moment and electronic spectroscopic data. The synthesized compounds were also investigated for their luminescent behavior which exhibited broad emission bands indicating charge transfer nature of the involved transitions.
\end{abstract}

KEY WORDS: Metal complexes, Mannich bases, 2-Mercaptobenzimidazole, Luminescence

\section{INTRODUCTION}

Mannich in 1912 reported first "Mannich base", in which two different chemical moieties formed linkage by means of methylene bridge $\left(-\mathrm{CH}_{2}-\right)$ [1]. The Mannich bases have played a vital role in the development of synthetic organic chemistry due to the versatile reactivity of these compounds. They are very reactive, useful intermediates of synthetic chemistry and can easily be transformed into variety of new compounds [2,3]. The "Mannich reaction" is the nucleophilic addition reaction of non enolizable aldehyde (mostly formaldehyde) and an amine (primary, secondary or ammonia) to form resonance stabilized imine (iminium ion or imine salt) and then allowed to react with the substrate involving active hydrogen containing (any enolizable carbonyl compound, nitriles, amide, carbamate, electron-rich heterocycles such as furan, pyrrole, and thiophene, or urea) [4-6]. Benzimidazole is an interesting precursor in this direction. A literature survey reveals that benzimidazole derivatives exhibit several biological and pharmaceutical properties such as anti-inflammatory, anti-HIV, anticancer, antiviral, antihelmintic, antitubercular, antipsychotic etc [7-19]. It is well established that combining two or more active moieties may possibly augment the activity and more particularly prevent the development of resistance by the infectious micro-organisms [8].

*Corresponding author. E-mail: imran_inorganic@yahoo.com,ktm7ro@yahoo.com

This work is licensed under the Creative Commons Attribution 4.0 International License 
Keeping in view structural diversity and enormous applications of Mannich bases, in the present work, synthetic strategies for the previously synthesized [20-21] two Mannich bases [1(di- $n$-butylamine- $N$-methyl)mercapto- $1 H$-benzimidazole] $\left(\mathbf{L}^{\mathbf{1}}\right)$ and [1-(diphenylamine- $N$-methyl) mercapto-1H-benzimidazole] $\left(\mathbf{L}^{2}\right)$ derived from 2-mercaptobenzimidazole and their eight transition metal complexes have been developed. The structural and bonding aspects of the synthesized compounds and their luminescent behavior are part of this manuscript.

\section{EXPERIMENTAL}

\section{Materials}

All reagents, 2-mercaptobenzimidazole (M.p: $300-304{ }^{\circ} \mathrm{C}$ ), methanol (B.p: $64.7^{\circ} \mathrm{C}$ ), THF (B.p: $66^{\circ} \mathrm{C}$ ), diphenylamine, di- $n$-butylamine, $\mathrm{CoCl}_{2}, \mathrm{NiCl}_{2}, \mathrm{CuCl}_{2}, \mathrm{ZnCl}_{2}$ were procured from Sigma Aldrich and used without further purification.

\section{Analytical methods}

UV/Visible spectrophotometer (model T90+), FT-IR spectrophotometer (Cary 630 FT-IR), Atomic absorption spectrophotometer (Perkin Elmer AA Analyst 100), Conductivitymeter (Cyber scan 500 con), PerkinElmer multimode plate reader for photoluminescence and Avance 500 Nuclear magnetic spectrometer for ${ }^{1} \mathrm{H}$ and ${ }^{13} \mathrm{C}$ NMR were used to characterize the synthesized compounds. The melting points were determined by Gallen Kemp apparatus.

\section{Synthesis of ligands}

Mannich base $\left(\boldsymbol{L}^{\mathbf{l}}\right)$. Ligand [1-(di- $n$-butylamine- $N$-methyl)mercapto- $1 H$-benz-Imidazole], $\left(\mathbf{L}^{\mathbf{1}}\right)$ was synthesized according to a reported procedure [20] with the slight modifications particularly with reference to solvents used and reflux time. Briefly, equimolar solutions of di- $n$-butylamine $(0.01 \mathrm{~mol}, 1.7 \mathrm{~mL})$ and paraformaldehyde $(0.01 \mathrm{~mol}, 0.30 \mathrm{~g})$ in methanol, 2mercaptobenzimidazole $(0.01 \mathrm{~mol}, 1.5 \mathrm{~g})$ in tetrahydrofuran were mixed. The resulting mixture was stirred in an ice cold condition for about 30 minutes and then gradually heated to reflux for $5 \mathrm{~h}$. The resulting solid obtained was filtered, washed with $n$-hexane, dried and kept in dessicator (scheme 1).

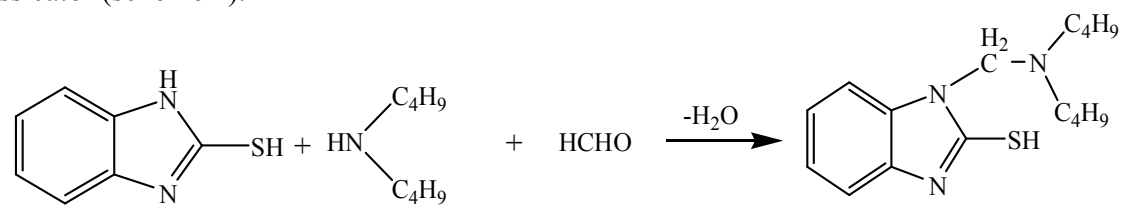

$\left(\mathbf{L}^{\mathbf{1}}\right)$

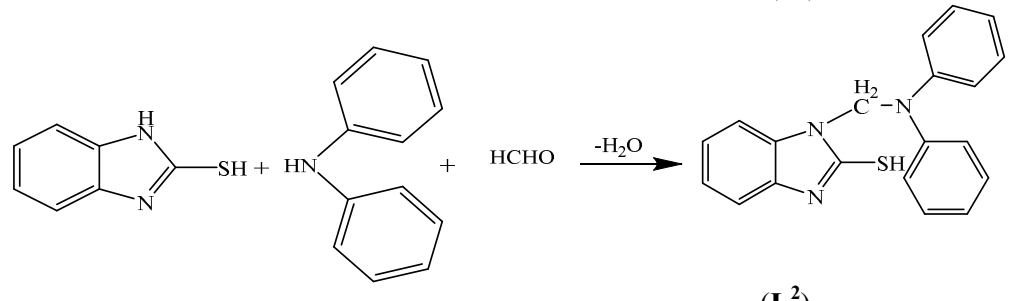

$\left(\mathbf{L}^{2}\right)$

Scheme 1. Synthesis route of ligands. 
Mannich base $\left(\boldsymbol{L}^{2}\right)$. Ligand [1-(diphenylamine- $N$-methyl)mercapto- $1 H$-benzimidazole] $\left(\mathrm{L}^{2}\right)$ was synthesized according to reported procedure [21] as by taking equimolar quantities of 2mercaptobenzimidazole $(0.01 \mathrm{~mol}, 1.5 \mathrm{~g})$, diphenylamine $(0.01 \mathrm{~mol}, 1.69 \mathrm{~g})$ and Paraformaldehyde $(0.01 \mathrm{~mol}, 0.30 \mathrm{~g})$ in $20 \mathrm{~mL}$ of methanol. (Scheme 1$)$.

General method for the synthesis of metal complexes

Metal complexes of $\mathbf{L}^{\mathbf{1}}$ [1-(di- $n$-butylamine- $N$-methyl)mercapto- $1 H$-benz-

Imidazole] and $\mathbf{L}^{2}$ [1-(diphenylamine- $N$-methyl)mercapto- $1 H$-benzimidazole] were synthesized by adding methanolic solution of ligands $\left(\mathbf{L}^{1}\right)(0.58 \mathrm{~g}, 0.002 \mathrm{~mol})$ and $\left(\mathbf{L}^{2}\right)(0.66 \mathrm{~g}, 0.002 \mathrm{~mol})$ dropwise with continuous stirring to methanolic solution of respective metal salts $\mathrm{CoCl}_{2}(0.129$ g, $0.001 \mathrm{~mol}), \mathrm{NiCl}_{2}(0.129 \mathrm{~g}, 0.001 \mathrm{~mol}), \mathrm{CuCl}_{2}(0.134 \mathrm{~g}, 0.001 \mathrm{~mol}), \mathrm{ZnCl}_{2}(0.136 \mathrm{~g}, 0.001$ $\mathrm{mol}$ ). The resulting solutions were stirred at room temperature for about $1 \mathrm{~h}$. Subsequently, the mixture were refluxed for $2 \mathrm{~h}$ and then cooled to room temperature. The resulting solids were filtered, washed with methanol thrice, dried and then stored in desiccator for further use (Scheme 2 and 3).

(a)

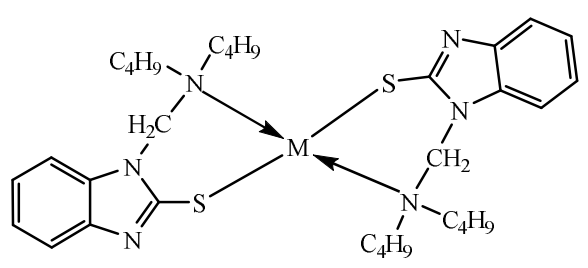

where, $\mathrm{M}=\mathrm{Co}^{2+}, \mathrm{Ni}^{2+}, \mathrm{Cu}^{2+}, \mathrm{Zn}^{2+}$

(b)

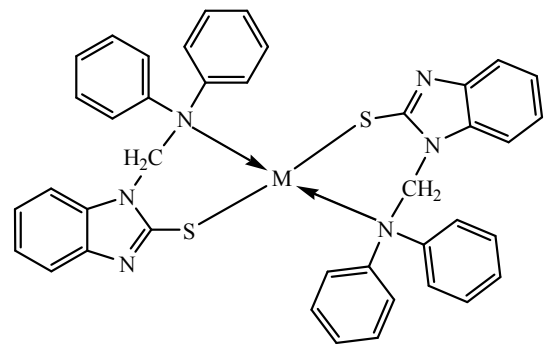

where, $\mathrm{M}=\mathrm{Co}^{2+}, \mathrm{Ni}^{2+}, \mathrm{Cu}^{2+}, \mathrm{Zn}^{2+}$

Scheme 2. Proposed structures of metal complexes (a) $\mathbf{L}^{\mathbf{1}}-\mathbf{M}$ (II) complexes and (b) $\mathbf{L}^{\mathbf{2}}-\mathbf{M}$ (II) complexes. 


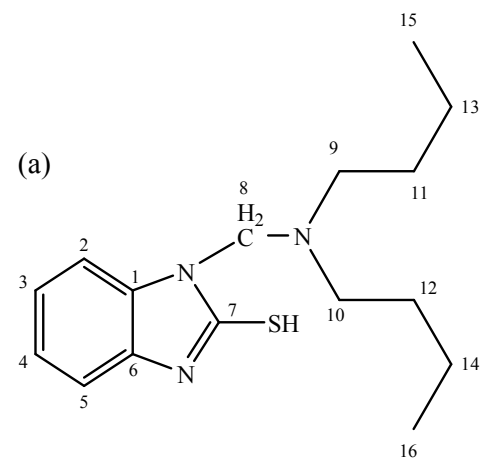

(b)<smiles>Sc1nc2ccccc2n1CN(c1ccccc1)c1ccccc1</smiles>

Scheme 3. Labeling of $\mathbf{L}^{1}$ and $\mathbf{L}^{2}$ for ${ }^{1} \mathrm{H} /{ }^{13} \mathrm{C}$ NMR spectral interpretation (a) $\mathbf{L}^{1}$ and (b) $\mathbf{L}^{2}$.

\section{RESULTS AND DISCUSSION}

Both the ligands $\mathrm{L}^{1}\left[1\right.$-(di- $n$-butylamine- $N$-methyl)mercapto- $1 H$-benz-imidazole and $\mathbf{L}^{2}[1$ (diphenylamine- $N$-methyl)mercapto-1H-benzimidazole] and their respective complexes were prepared by the general outlines given above in experimental section (Schemes 1 and 2). At room temperature each complex is stable solid towards air and moisture. All the complexes are colored except zinc complexes. Generally, these ligands and metal complexes are insoluble in most of the organic solvents, except DMSO and DMF. Moreover, the solubility of $\mathrm{L}^{2}$-metal complexes is quite low compared to fair solubility of $\mathrm{L}^{1}$-metal complexes. Physical properties of ligands and their respective metal complexes are shown in Table 1.S

Table1. Analytical data of the ligands and their complexes

\begin{tabular}{|c|c|c|c|c|c|c|}
\hline \multirow{2}{*}{$\begin{array}{l}\text { S. } \\
\text { No. }\end{array}$} & \multirow{2}{*}{ Compound } & \multirow{2}{*}{$\begin{array}{l}\text { Decomposition } \\
\text { point } /{ }^{\circ} \mathrm{C}\end{array}$} & \multirow{2}{*}{ Color } & \multirow{2}{*}{$\%$ Yield } & \multicolumn{2}{|c|}{$\begin{array}{c}\% \text { of metal } \mathrm{ML}_{2} \\
1: 2\end{array}$} \\
\hline & & & & & $\begin{array}{c}\text { Found } \\
(\%)\end{array}$ & $\begin{array}{c}\text { Calculated } \\
(\%)\end{array}$ \\
\hline 1 & Ligand $\mathrm{L}^{1}$ & $131-135$ & White & 72 & --- & --- \\
\hline 2 & Ligand $\mathrm{L}^{2}$ & $165-170$ & White & 70 & --- & --- \\
\hline 3 & $\mathrm{~L}^{\mathrm{L}-\mathrm{Co}(\mathrm{II}) \text { complex }}$ & $>210$ & Dark blue & 68 & 9.7 & 10.1 \\
\hline 4 & $\mathrm{~L}^{1}-\mathrm{Ni}$ (II) complex & $>190$ & Bright green & 71 & 9.8 & 10.0 \\
\hline 5 & $\mathrm{~L}^{\mathrm{I}-\mathrm{Cu}(\mathrm{II}) \text { complex }}$ & $>250$ & Bright blue & 78 & 10.0 & 10.9 \\
\hline 6 & $\mathrm{~L}^{\mathrm{I}}-\mathrm{Zn}(\mathrm{II})$ complex & $>180$ & White & 60 & 10.9 & 11.2 \\
\hline 7 & $\mathrm{~L}^{2}-\mathrm{Co}(\mathrm{II})$ complex & $>220$ & Bright blue & 75 & 8.26 & 8.87 \\
\hline 8 & $\mathrm{~L}^{2}-\mathrm{Ni}$ (II) complex & $>200$ & Dark green & 72 & 8.44 & 8.84 \\
\hline 9 & $\mathrm{~L}^{2}-\mathrm{Cu}(\mathrm{II})$ complex & $>250$ & Blue & 76 & 9.25 & 9.57 \\
\hline 10 & $\mathrm{~L}^{2}-\mathrm{Zn}$ (II) complex & $>170$ & White & 65 & 9.11 & 9.98 \\
\hline
\end{tabular}

FT-IR spectra

The well-defined peaks of [1-(di- $n$-butylamine- $N$-methyl)mercapto-1 $H$-benzimidazole] $\left(\mathbf{L}^{1}\right)$, [1(diphenylamine- $N$-methyl)mercapto-1 $H$-benzimidazole $]\left(\mathbf{L}^{2}\right)$ and their complexes were recorded in IR spectra ranging 4000-400 $\mathrm{cm}^{-1}$ and compared (Table 2). The peaks at 1619 and $1591 \mathrm{~cm}^{-1}$ can be assigned to $\mathrm{VC}=\mathrm{N}$ functional group present in the ring $\mathbf{L}^{1}$ and $\mathbf{L}^{2}$, respectively [21]. The presence of $\mathrm{C}=\mathrm{N}$ functional groups in $\mathbf{L}^{1}$ and $\mathbf{L}^{2}$ and absence of stretching frequencies for $\mathrm{C}=\mathrm{S}$ suggest that both the ligands exhibit enol tautomer $(\mathrm{C}-\mathrm{SH})$ instead of keto form $(\mathrm{C}=\mathrm{S})$. These 
proposed structures are well supported by ${ }^{13} \mathrm{C}$ NMR, where chemical shift of $\mathrm{C}-\mathrm{S}$ was observed at $167 \mathrm{ppm}$ clarifying thiol $(\mathrm{C}-\mathrm{SH})$ moiety instead of $\mathrm{C}=\mathrm{S} .{ }^{13} \mathrm{C}$ NMR is a best tool to distinguish between $\mathrm{C}-\mathrm{SH}$ and $\mathrm{C}=\mathrm{S}$, for $\mathrm{C}=\mathrm{S}$, chemical shift appears above $190 \mathrm{ppm}$ [22]. The comparison of IR spectral data of ligands and metal complexes also revealed the coordination through nitrogen $(\mathrm{N})$ and sulfur $(\mathrm{S})$. The results are in agreement with [23-25].

Table2. IR assignments $\left(4000-700 \mathrm{~cm}^{-1}\right)$ of ligands $\mathbf{L}^{1}, \mathbf{L}^{2}$ and their metal complexes

\begin{tabular}{|c|c|c|c|}
\hline Compound & $\begin{array}{c}v(\mathrm{C}=\mathrm{N}) \mathrm{cm}^{-1} \\
(\text { Aromatic })\end{array}$ & $\begin{array}{c}v\left(\mathrm{CH}_{2}\right) \\
\mathrm{cm}^{-1}\end{array}$ & $\begin{array}{c}v(\mathrm{C}-\mathrm{N}-\mathrm{C}) \\
\mathrm{cm}^{-1}\end{array}$ \\
\hline Ligand $\mathbf{L}^{1}$ & 1619 & 1466 & 1358 \\
\hline Ligand $\mathbf{L}^{2}$ & 1591 & 1460 & 1335 \\
\hline $\mathrm{L}^{1}-\mathrm{Co}(\mathrm{II})$ complex & 1655 & 1459 & 1230 \\
\hline $\mathrm{L}^{1}-\mathrm{Ni}(\mathrm{II})$ complex & 1625 & 1454 & 1239 \\
\hline $\mathrm{L}^{1}-\mathrm{Cu}(\mathrm{II})$ complex & 1619 & 1421 & 1346 \\
\hline $\mathrm{L}^{1}-\mathrm{Zn}(\mathrm{II})$ complex & 1621 & 1456 & 1346 \\
\hline $\mathrm{L}^{2}-\mathrm{Co}(\mathrm{II})$ complex & 1619 & 1460 & 1334 \\
\hline $\mathrm{L}^{2}-\mathrm{Ni}(\mathrm{II})$ complex & 1619 & 1415 & 1350 \\
\hline $\mathrm{L}^{2}-\mathrm{Cu}(\mathrm{II})$ complex & 1620 & 1456 & 1346 \\
\hline $\mathrm{L}^{2}-\mathrm{Zn}(\mathrm{II})$ complex & 1578 & 1493 & 1338 \\
\hline
\end{tabular}

${ }^{1} H$ NMR spectra

The ${ }^{1} \mathrm{H}$ NMR spectra of the Mannich bases $\mathbf{L}^{1}$ and $\mathbf{L}^{2}$ and their complexes were recorded in DMSO- $d_{6}$ (Table 3). For assigning chemical shifts to the various protons, the structures of both these ligands have been labeled (Scheme 3). The ${ }^{1} \mathrm{H}$ NMR spectra of $\mathbf{L}^{\mathbf{1}}$ and $\mathbf{L}^{\mathbf{2}}$ exhibit a multiplets in the range $\delta 6.67-7.49$ and $\delta 6.78-7.50 \mathrm{ppm}$ respectively, which can be attributed to aromatic protons. Both the ligands $\mathbf{L}^{1}$ and $\mathbf{L}^{2}$ show a singlet at $\delta 5.67$ and $\delta 5.69 \mathrm{ppm}$ respectively, which can be assigned to methylene linkage $\left(2 \mathrm{H},-\mathrm{CH}_{2}\right)$ formed between the benzimidazole moiety and amino compound (Table 3 ). In the metal complexes, the very fine information was not observed because of the broadness of signals except zinc complexes (Table 3) making the interpretation complicated. However, shifting of chemical shift values of protons in the down field region may be attributed to the involvement of ligand with metal ions [24, 25] as elucidated on the basis of FT-IR.

Table 3. ${ }^{1} \mathrm{H}$ NMR data of Mannich bases and their Zinc complexes

\begin{tabular}{|c|l|}
\hline Compound & \multicolumn{1}{|c|}{$\delta / \mathrm{ppm}$} \\
\hline & $\left(\mathrm{DMSO}-d_{6}, 500 \mathrm{MHz}, \delta\right)$ \\
& $6.67-7.49(\mathrm{~m}, 4 \mathrm{H}, \mathrm{ArH}), 5.67\left(\mathrm{~s}, 2 \mathrm{H}, \mathrm{CH}_{2}\right), 1.25-2.49(\mathrm{~m}$, \\
& $\left.12 \mathrm{H}, \mathrm{CH}_{2}\right), 0.89\left(\mathrm{~m}, 6 \mathrm{H}, \mathrm{CH}_{3}\right)$. \\
\hline \multirow{2}{*}{$\mathbf{L}^{2}$} & $\left(\mathrm{DMSO}-\mathrm{d}_{6}, 400 \mathrm{MHz}\right)$ \\
& $\left(\mathrm{DMSO}-d_{6}, 400 \mathrm{MHz}, \delta\right): 6.78-7.50(\mathrm{~m}, 14 \mathrm{H}, \mathrm{ArH}) ; 5.69(\mathrm{~s}$, \\
& $\left.2 \mathrm{H}, \mathrm{CH}_{2}\right)$. \\
\hline & $\left(\mathrm{DMSO}-\mathrm{d}_{6}, 400 \mathrm{MHz}\right)$ \\
& $6.65-7.85(\mathrm{~m}, 8 \mathrm{H}, \mathrm{ArH}) ; 5.56\left(\mathrm{~s}, 4 \mathrm{H}, \mathrm{CH}_{2}\right) ; 1.30-2.49(\mathrm{~m}$, \\
& $\left.24 \mathrm{H}, \mathrm{CH}_{2}\right) ; 0.84\left(\mathrm{~m}, 12 \mathrm{H}, \mathrm{CH}_{3}\right)$ \\
\hline \multirow{2}{*}{$\mathrm{L}^{1}-\mathrm{Zn}(\mathrm{II})$ complex } & $\left(\mathrm{DMSO}-d_{6}, 400 \mathrm{MHz}\right)$ \\
& $6.07-7.12(\mathrm{~m}, 28 \mathrm{H}, \mathrm{ArH}) ; 4.15\left(\mathrm{~s}, 4 \mathrm{H}, \mathrm{CH}_{2}\right)$. \\
\hline
\end{tabular}


${ }^{13}$ CNMR spectra

The ${ }^{13} \mathrm{C}$ NMR spectra of the Mannich bases $\mathbf{L}^{1}, \mathbf{L}^{2}$ and their metal complexes were recorded in DMSO- $d_{6}$ and the chemical shifts of various carbons have been given in Table 4 . The prominent chemicals shifts at $\delta 168.9 \mathrm{ppm}$ can be assigned to the thiol carbon (C7). Similarly chemical shifts at $\delta 67.05$ and $67.07 \mathrm{ppm}$ in $\mathbf{L}^{1}$ and $\mathbf{L}^{2}$ can be assigned to the methylene carbon $\mathrm{C} 8$ and C20 (a linkage between benzimidazole moiety and amino compounds), respectively (Table 4). In respective zinc complexes, the chemical shift of $\mathrm{C} 7$ carbon has been observed at 189.7 and 189.9 ppm suggesting coordination through thiol moiety. Moreover, there is also change in chemical shift values C8 and C20 (surrounding nitrogen atoms of amine moiety) in these complexes revealing involvement of these nitrogen atoms in coordination with zinc ions (Table 4).

Table $4 .{ }^{13} \mathrm{C}$ NMR data of Mannich bases and their Zinc complexes

\begin{tabular}{|c|c|}
\hline Compound & $\delta / \mathrm{ppm}$ \\
\hline $\mathbf{L}^{1}$ & $\begin{array}{l}\left.\text { (DMSO- } d_{6}, 500 \mathrm{MHz}, \delta\right) \\
67.07(\mathrm{C} 8) ; 110.15,123.05,131.11(\mathrm{C} 1-\mathrm{C} 6) ; 168.99 \text { (C7); } \\
23.20-39.91(\mathrm{C} 9-\mathrm{C} 12) ; 10.75(\mathrm{C} 15, \mathrm{C} 16)\end{array}$ \\
\hline $\mathbf{L}^{2}$ & $\begin{array}{l}\left.\text { (DMSO- } d_{6}, 400 \mathrm{MHz}, \delta\right) \\
67.05 \quad(\mathrm{C} 20) ; 116.70-143.40 \quad(\mathrm{C} 1-\mathrm{C} 6, \mathrm{C} 8-\mathrm{C} 19) ; 168.97 \\
(\mathrm{C} 7) .\end{array}$ \\
\hline $\mathrm{L}^{1}-\mathrm{Zn}(\mathrm{II})$ complex & $\begin{array}{lllll}\left.\text { (DMSO- } d_{6}, 400 \mathrm{MHz}, \delta\right) & & & \\
67.40 \quad(\mathrm{C} 8) ; \quad 109.42-141.31 \quad(\mathrm{C} 1-\mathrm{C} 6) ; & 189.70 & (\mathrm{C} 7) ; \\
23.20-39.91(\mathrm{C} 9-\mathrm{C} 12) ; 10.75(\mathrm{C} 15, \mathrm{C} 16) . & & \end{array}$ \\
\hline $\mathrm{L}^{2}-\mathrm{Zn}(\mathrm{II})$ complex & $\begin{array}{l}\left.\text { (DMSO- } d_{6}, 400 \mathrm{MHz}, \delta\right) \\
66.05 \quad(\mathrm{C} 20) ; 109.21-131.97 \quad(\mathrm{C} 1-\mathrm{C} 6, \mathrm{C} 8-\mathrm{C} 19) ; 188.97 \\
(\mathrm{C} 7) .\end{array}$ \\
\hline
\end{tabular}

\section{UV/Vis data and Magnetic moment}

Electronic spectrum of the $\mathrm{Co}(\mathrm{II})$-complexes illustrated two allowed transitions assignable to ${ }^{4} \mathrm{~A}_{2}(\mathrm{~F}) \rightarrow{ }^{4} \mathrm{~T}_{1}(\mathrm{~F})\left(11708-11721 \mathrm{~cm}^{-1}\right)$ and ${ }^{4} \mathrm{~A}_{2}(\mathrm{~F}) \rightarrow{ }^{4} \mathrm{~T}_{1}(\mathrm{P})\left(17413-17456 \mathrm{~cm}^{-1}\right)$ which were in good agreement with tetrahedral geometry for $\mathrm{Co}(\mathrm{II})$ ions. The magnetic moment values of $\mathrm{Co}$ (II) complexes were 4.31 B.M., 4.36 B.M., revealing that both Co (II) complexes have typical tetrahedral geometry [26]. Ni (II) complexes depicted two absorption bands in their electronic spectrum at $11646-11676 \mathrm{~cm}^{-1}$ and $15456-15470 \mathrm{~cm}^{-1}$ assignable to ${ }^{3} \mathrm{~T}_{1}(\mathrm{~F}) \rightarrow{ }^{3} \mathrm{~A}_{2}(\mathrm{~F}),{ }^{3} \mathrm{~T}_{1}(\mathrm{~F}) \rightarrow$ ${ }^{3} \mathrm{~T}_{1}(\mathrm{P})$ transitions which revealed the tetrahedral environment around $\mathrm{Ni}(\mathrm{II})$ ion. Similarly, the magnetic moment values (3.31 B.M., 3.20 B.M.) also support this environment around Ni (II) ions [27]. $\mathrm{Cu}$ (II) complexes in their electronic spectra show an absorption band at 13146 and $13233 \mathrm{~cm}^{-1}$ that can be assigned to ${ }^{2} \mathrm{~T}_{2} \rightarrow{ }^{2} \mathrm{E}$ transition of tetrahedral geometry. The magnetic moment values (2.21 B.M., 2.13 B.M.) of these complexes also support 4-coordinate tetrahedral geometry and presence of one unpaired electron in $d^{9}$ [28]. Zn (II) complexes have $d^{10}$ configuration and were found to be diamagnetic. The diamagnetic nature of this complex supports only presence of charge transfer band and absence of $\mathrm{d}$ - $\mathrm{d}$ transition proposing its tetrahedral geometry $[28,29]$.

\section{Photo-physical studies}

The fluorescence emission spectra of the Mannich bases $\mathbf{L}^{\mathbf{1}}, \mathbf{L}^{\mathbf{2}}$ and their transition metal complexes were recorded at excitation wavelength 320 and $520 \mathrm{~nm}$ at room temperature. The fluorescence emission spectrum of $\mathbf{L}^{\mathbf{1}}, \mathbf{L}^{2}$ and their transition metal complexes are depicted in 
Figures 1 and 2. Both the ligands and their metal complexes showed broad emission bands indicating charge transfer nature of the transitions. Significant differences in positions of emission maximum from those of the ligand and metal complexes establish the complexation process [28]. At excitation wavelength $320 \mathrm{~nm}, \mathbf{L}^{1}$ and $\mathbf{L}^{2}$ showed the emission at 426 and 359 $\mathrm{nm}$, and their complexes showed the emission at 370, 416, 430, 425, 427, 359, 386 and $368 \mathrm{~nm}$ for $\mathrm{L}^{1}-\mathrm{Co}(\mathrm{II}), \mathrm{L}^{1}-\mathrm{Ni}(\mathrm{II}), \mathrm{L}^{1}-\mathrm{Cu}(\mathrm{II}), \mathrm{L}^{1}-\mathrm{Zn}(\mathrm{II}), \mathrm{L}^{2}-\mathrm{Co}(\mathrm{II}), \mathrm{L}^{2}-\mathrm{Ni}(\mathrm{II}), \mathrm{L}^{2}-\mathrm{Cu}(\mathrm{II})$ and $\mathrm{L}^{2}-\mathrm{Zn}(\mathrm{II})$, respectively. $\mathrm{L}^{2}, \mathrm{~L}^{2}-\mathrm{Zn}$ (II) and $\mathrm{L}^{1}-\mathrm{Co}(\mathrm{II})$ showed strong fluorescence emission with high intensity as compared to others due to different electronic configurations of metal ions and metal-charge transfer transition. At excitation wavelength $520 \mathrm{~nm}, \mathbf{L}^{1}$ and $\mathbf{L}^{2}$ showed the strong fluorescence emission at 520 and $523 \mathrm{~nm}$. Their complexes showed the emission at 525, 522, $520,519,518,519,521$ and $520 \mathrm{~nm}$ for $\mathrm{L}^{1}-\mathrm{Co}(\mathrm{II}), \mathrm{L}^{1}-\mathrm{Ni}(\mathrm{II}), \mathrm{L}^{1}-\mathrm{Cu}(\mathrm{II}), \mathrm{L}^{1}-\mathrm{Zn}(\mathrm{II}), \mathrm{L}^{2}-\mathrm{Co}(\mathrm{II}), \mathrm{L}^{2}-$ $\mathrm{Ni}(\mathrm{II}), \mathrm{L}^{2}-\mathrm{Cu}(\mathrm{II})$ and $\mathrm{L}^{2}-\mathrm{Zn}(\mathrm{II})$, respectively. Among other metal complexes, the $\mathrm{L}^{1}-\mathrm{Zn}(\mathrm{II})$ and $\mathrm{L}^{2}-\mathrm{Zn}$ (II) complexes exhibited, the enhanced fluorescent intensity, was attributed to ligand to metal charge transfer (LMCT) transitions and diamagnetic nature ( $d^{10}$ configuration) of $\mathrm{Zn}$ (II) ions, which significantly increase the emission lifetime. The factors, which are assigned to be responsible for increase in the photoluminescence, are the simple binding of ligand to the $d^{10}$ metal ions, an increased rigidity in structure of the complexes and a restriction in the photo induced electron transfer, etc [29, 30]. It is evident from the fluorescence spectra that fluorescence emission intensity of Mannich bases changed dramatically on complex formation with transition metal ions. The change in fluorescence intensity with formation of metal complexes is due to change in electron density on Mannich bases [31].

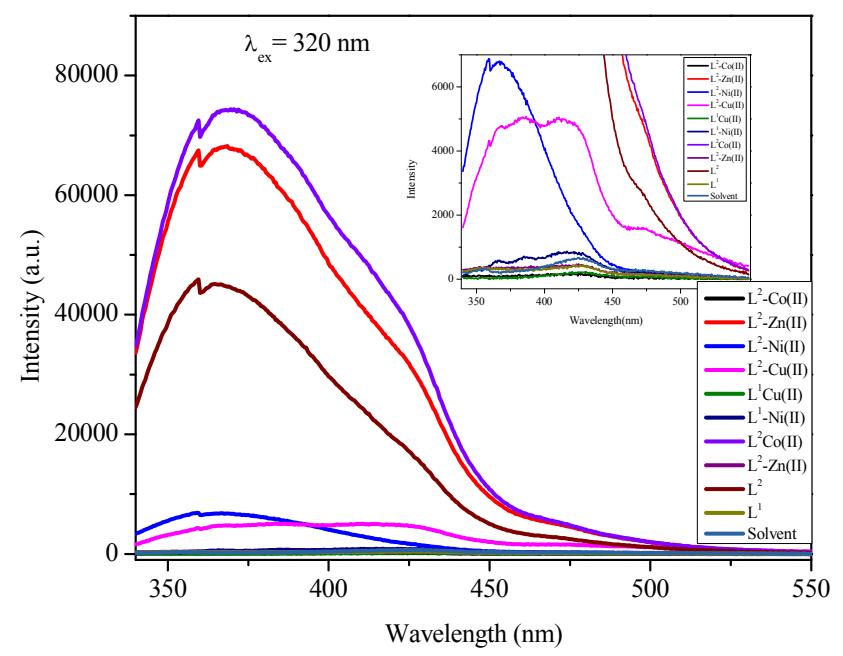

Figure 1. Fluorescence spectra at excitation wavelength $320 \mathrm{~nm}$. 


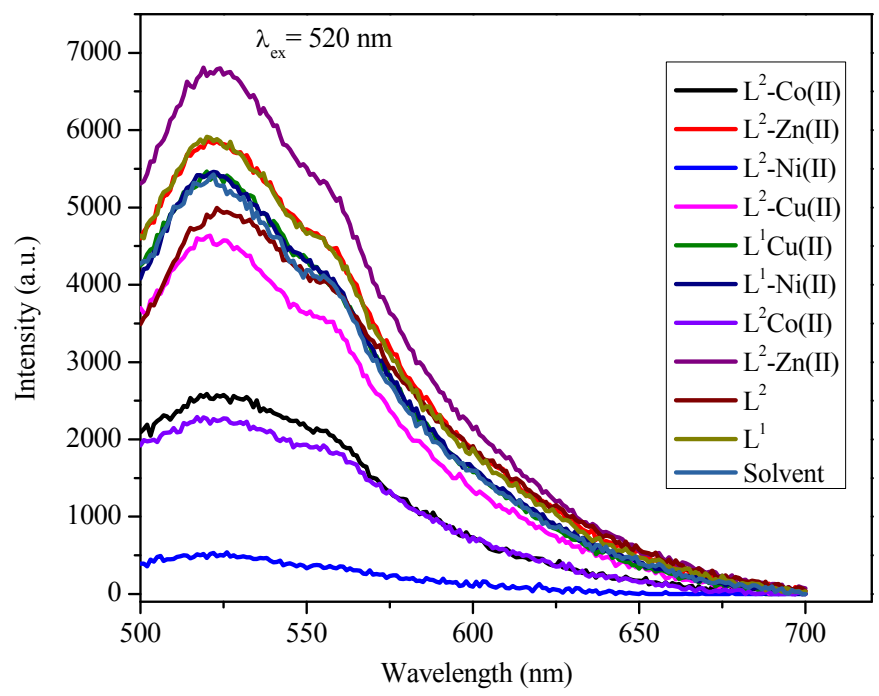

Figure 2. Fluorescence spectra at excitation wavelength $520 \mathrm{~nm}$.

\section{CONCLUSION}

In this study, we have explored the synthesis and coordination chemistry of two previously synthesized Mannich base ligands and their eight transition metal complexes. The structural elucidation revealed that both the ligands behave in a monoanionic bidentate fashion. The geometries of all the resulting complexes were found to be tetrahedral. The metal complexes of both sulfur based Mannich bases were found to possess appreciable luminescence activity. It is evident from the fluorescence spectra that fluorescence emission intensity of $\mathbf{L}^{1}$ and $\mathbf{L}^{2}$ changed dramatically on complex formation and maximum fluorescence emission was showed by $\mathrm{L}^{1}$ $\mathrm{Zn}(\mathrm{II})$ and $\mathrm{L}^{2}-\mathrm{Zn}(\mathrm{II})$ complexes.

\section{ACKNOWLEDGMENT}

The authors are thankful to the Higher Education Commission of Pakistan for providing characterization facilities through access to scientific instruments program.

\section{REFERENCES}

1. Mannich, C.; Krösche, W. About a condensation product of formaldehyde, ammonia and antipyrine. Arch.Pharm. 1912, 250, 647-667.

2. Tramontini, M. Advances in the chemistry of Mannich bases. Synthesis 1973, 1973, 703775 .

3. Tramontini, M.; Angiolini, L. Mannich Bases-Chemistry and Uses, Vol. 5, CRC Press: Boca Raton; 1994. 
4. Wang, Z. Mannich Reaction, Comprehensive Organic Name Reactions and Reagents, John Wiley and Sons: New York; 2010.

5. List, B. The direct catalytic asymmetric three-component Mannich reaction. J. Am. Chem. Soc. 2000, 122, 9336-9337.

6. Bala, S.; Sharma, N.; Kajal, A.; Kamboj, S.; Saini, V.; Mannich bases: An important pharmacophore in present scenario, Int. J. Med. Chem. 2014, 1-15.

7. El-Masry, A.H.; Fahmy, H.; Ali Abdelwahed, S. Synthesis and antimicrobial activity of some new benzimidazole derivatives. Molecules 2000, 5, 1429-1438.

8. Ahmadi, A. Synthesis and antibacterial evaluation of some novel Mannich bases of benzimidazole derivatives. Bull. Chem. Soc. Ethiop. 2016, 30, 421-425.

9. Reddy, B.A. Synthesis, characterization and biological evaluation of 1,2-disubstituted benzimidazole derivatives using Mannich bases. E-J. Chem. 2010, 7, 222-226.

10. Shah, T.; Gupte, A.; Patel, M.; Chaudhari, V.; Patel, H.; Patel, V. Synthesis and in vitro study of biological activity of heterocyclic N-Mannich bases. Indian J. Chem. 2009, 48, 8896.

11. Kalluraya, B.; Chimbalkar, R.M.; Hegde, J.C. Anticonvulsant activity of nicotinyl/isonicotinyl substituted 1,2,4-triazol-5-thione Mannich bases. Indian J. Heterocycl. Chem. 2005, 15, 15-18.

12. Köksal, M.; Gökhan, N.; Küpeli, E.; Yesilada, E.; Erdogan, H. Analgesic and antiinflammatory activities of some new mannich bases of 5-nitro-2-benzoxazolinones. Arch. Pharm. Res. 2007, 30, 419-424.

13. Sriram, D.; Banerjee, D.; Yogeeswari, P. Efavirenz Mannich bases: Synthesis, anti-HIV and antitubercular activities. J. Enzym. Inhib. Med. Chem. 2009, 24, 1-5.

14. Gul, H.I.; Vepsalainen, J.; Gul, M.; Erciyas, E.; Hanninen, O. Cytotoxic activities of mono and bis Mannich bases derived from acetophenone against Renca and Jurkat cells. Pharm. Acta Helv. 2000, 74, 393-398.

15. Ivanova, Y.; Momekov, G.; Petrov, O.; Karaivanova, M.; Kalcheva, V. Cytotoxic Mannich bases of 6-(3-aryl-2-propenoyl)-2(3H)-benzoxazolones. Eur. J. Med. Chem. 2007, 42, 13821387.

16. Edwards, M.; Ritter, H.; Stemerick, D.; Stewart, K. Mannich bases of 4-phenyl-3-buten-2one. A new class of antiherpes agent. J. Med. Chem. 1983, 26, 431-436.

17. Bennet-Jenkins, E.; Bryant, C. Novel sources of anthelmintics. Int. J. Parasitol. 1996, 26, 937-947.

18. Mulla, J.; Khan, A.; Panchamukhi, S.; Khazi, M.; Kalashetti, M.; Khazi, I. Synthesis and antitubercular activity of Mannich bases of imidazo [2,1-b][1,3,4]thiadiazoles. Indian J. Novel Drug Deliv. 2011, 3, 289-295.

19. Scott, M.K.; Martin, G.E.; DiStefano, D.L.; Fedde, C.L.; Kukla, M.J.; Barrett, D.L.; Baldy, W.J.; Elgin Jr., R.J.; Kesslick, J.M. Pyrrole mannich bases as potential antipsychotic agents. J. Med. Chem. 1992, 35, 552-558.

20. Zhang, J.; Liu, W.; Xue, Q. Tribological study of a mannich compound of 2 mercaptobenzimidazole in liquid paraffin. Tribol. Int. 1998, 31, 767-770.

21. Anandarajagopal, K.; Tiwari, R.N.; Venkateshan, N.; Pooshan, G.; Promwichit, P. Synthesis and characterization of 2-mercaptobenzimidazole derivatives as potential analgesic agents. J. Chem. Pharm. Res. 2010, 2, 230-236.

22. Balestrero, R.; Forkey, D.; Russell, J. ${ }^{15} \mathrm{~N}$ NMR: Iminothiol-thioamide tautomerism of 2-mercaptobenzazoles and 1-methyl-2-mercaptoimidazole. Magn. Reson. Chem. 1986, 24, 651-655.

23. Rehman, M. Ur; Imran, M.; Arif, M.; Farooq, M. Metal-based Antimicrobial agents: Synthesis, characterization and biological studies of Mannich base derivatives of benzimidazole and their metal complexes. Sci. J. Chem. 2013, 1, 56-66. 
24. Raman, N.; Esthar, S.; Thangaraja, C. A new Mannich base and its transition metal(II) complexes - synthesis, structural characterization and electrochemical study. J. Chem. Sci. 2004, 116, 209-213.

25. Mohanan K.; Murukan, B. Complexes of manganese(II), iron(II), cobalt(II), nickel(II), copper(II), and zinc(II) with a bishydrazone. Synth. React. Inorg. Met. Org. Nano-Met. Chem. 2005, 35, 837-844.

26. Lin, C.Y.; Chen, J.H.; Tung, J.Y. Molecular structures of cobalt complexes of 2-aza-2- $[p-$ methylbenzyl $]-5,10,15,20$-tetraphenyl-21-carbaporphyrin: $\quad\left[\mathrm{Co}\left(2-\mathrm{NCH}_{2}-p-\mathrm{C}_{6} \mathrm{H}_{4} \mathrm{CH}_{3}-21-m-\right.\right.$ $\left.\left.\mathrm{CH}_{2} \mathrm{C}_{6} \mathrm{H}_{4} \mathrm{CH}_{3} \mathrm{NCTPP}\right) \mathrm{L}\right]$ (L=Cl-, N*CS-). Polyhedron 2018 139, 237-242.

27. Sevgi, F.; Bagkesici, U.; Kursunlu, A.N.; Guler, E. Fe(III), Co(II), Ni(II), Cu(II) and Zn(II) complexes of Schiff bases based-on glycine and phenylalanine: Synthesis, magnetic/thermal properties and antimicrobial activity. J. Mol. Struct. 2018, 1154, 256-260.

28. Sumrra, S.H.; Hanif, M.; Chohan, Z.H.; Akram, M.S.; Akhtar, J.; Al-Shehri, S.M. Metal based drugs: Design, synthesis and in-vitro antimicrobial screening of $\mathrm{Co}(\mathrm{II}), \mathrm{Ni}(\mathrm{II}), \mathrm{Cu}(\mathrm{II})$ and $\mathrm{Zn}$ (II) complexes with some new carboxamide derived compounds: Crystal structures of $\mathrm{N}$-[ethyl(propan-2-yl)carbamothioyl]thiophene-2-carboxamide and its copper(II) complex. J. Enzyme Inhib. Med. Chem. 2016, 31, 590-598.

29. Orojloo, M.; Zolgharnein, P.; Solimannejad, M.; Amani, S. Synthesis and characterization of cobalt(II), nickel(II), copper(II) and zinc(II) complexes derived from two Schiff base ligands: Spectroscopic, thermal, magnetic moment, electrochemical and antimicrobial studies. Inorg. Chim. Acta 2017, 467, 227-237.

30. Souza, R.F.; De Giovani, W.F. Synthesis, spectral and electrochemical properties of Al(III) and $\mathrm{Zn}(\mathrm{II})$ complexes with flavonoids. Spectrochim. Acta Part A: Mol. Biomol. Spectros. 2005, 61, 1985-1990.

31. Zheng, S.L.; Yang, J.H.; Yu, X.L.; Chen, X.M.; Wong, W.T. Syntheses, structures, photoluminescence, and theoretical studies of $\mathrm{d}^{10}$ metal complexes of 2,2'-dihydroxy-[1,1] binaphthalenyl-3,3-dicarboxylate. Inorg. Chem. 2004, 43, 830-838. 